\title{
Analysing the Painful Recountal of Dalit Women in Baby Kamble's The Prisons We Broke
}

\author{
Mohd Nageen Rather \\ Asst. Professor English, Islamic University of Science and Technology(IUST) Awantipora \\ Jammu \& Kashmir, India \\ nigeenrather121@gmail.com
}

\begin{abstract}
Dalit Literature represents a powerful, emerging movement in the Indian literary traditionand its reverberations are now being heard all around the world. One more addition to the Dalit literature is Baby Kamble's autobiography The Prisons We Broke which portrays the socio-economical, cultural and political conditions of Dalit community in Indian society. It highlights the plight of Dalit women who receive inhuman treatment and suffer at every front. In Indian society women are always subjected to a subaltern state and are marginalized. Women face subjugation in various forms everywhere in India, traditional taboos legitimize their exploitation. For Dalit women, the situation is even worse, as they suffer from the triple oppression becauseof their gender, economical condition and their low caste.

This paper is an attempt to deliberate on the harsh realities of struggle, subjugation and suffering of Dalit women as depicted in The Prisons We Broke. As we know Dalit women are positioned at the lowest rung of the social hierarchy they are subjected to inhumane living conditions, violence and discrimination which deprive them of opportunities, choices and freedoms in all sphere of their life.
\end{abstract}

Keywords: Dalit Community, Women, Subaltern, Exploitation, Hierarchy, Violence

\section{INTRODUCTION}

Since autobiography is not only the story that demonstrates the saga of individual but also depicts sorrows, sufferings, subjugation and socio-economical conditions in a society, it is enjoyed as a literary genre all over the world and its literary significance is recognized by all and sundry. Similarly Baby Kamble's autobiography mentions certain important issues like caste discrimination, women subjugation and the influence of Dr. Ambedkar on Dalit women to get them educated both socially and culturally. Written in Marathi as Jina Amachain1985, it wastranslated into English by Prof. Maya Pandit.It deals mainlywith the lives of Mahar men and women in Kamble's village Veergaon in the state of Maharashtra. The text provides a painful and realistic picture of the oppressive caste and patriarchal beliefs of the Indian society especially that of her own community.

Kamble's The Prisons We Broke is considered not as her personal autobiography but can be termed as the autobiography of an oppressed and subjugated Dalit women who wish that her unheard sufferings is gifted with an audible voice. As Maya Pandit examines, "The Prisons We Broke is an expression of protest against the inhuman conditions of existence to which the Hindu caste system has subjected the Dalit for thousands of years". Baby Kamble beautifully tried to depict the pitiable situation of Mahar's in Maharashtra. She describes the mental and physical violence against women by the public and private spheres. 


\section{DISCUSSION}

Dalits are the people who are considered impure, dirty and untouchable as they belong to the lowest rung in Hindu hierarchal system, and are excommunicated from the Hindu society. They were termed as untouchables and dirty by the sacred Hindu Vedas and were subjected to the meanest jobs such as sweeping, husbandry and scavenging. Women, who already have a secondary status in society, face a double pressure as they belong to a Dalit community. They are subjugated in and outside the home. They never enjoy honour and dignity which should be due to them; rather they are the soft targets of all the forms of discrimination in Indian society.Kamble has gone deep into her memory and brings to the surface the plight of Dalit women. Her autobiography is filled with heart wrenching passages of miseries and sufferings of women who are made to receive the inhuman treatment without any fault of their own. There is hardly any place where women could feel secure and heave a sigh of relief. Their lives are made hell at every stage and every place is no less than a torture centre for them. They are made to suffer in every form whether it is physical, economical, social and psychological.

The discrimination to Mahar community begins from the very childhood days till end. In the book we come to know that all Mahar girls are neglected in school by upper caste girls because of the fear of getting polluted. Even if upper caste girls pass by them they would cover their nose, and run away as if these Dalit girls are not humans but foul- smelling corpses. One of the upper caste girls says that she was made to have a bath after she reached home from school as her mother didn't allow her in because she had come to know that Mahar girls too sit in that class.

Kamble presents an unflinching portrait of Dalit women, subjugated triplyby gender, caste and patriarchy. Especially newly married younger women suffer the worst fate. Girls are usually married off at the early age of eight or nine marriage for them turns out to be nothing but a big calamity.The first duty of the newlywedded daughter-in-law was to prepare bhakris so that she could prove her culinary skills. She had to do all the household chores without being given the chance of making any complaints. They can never expect a compliment in return from their in-laws butif a girl could not do the house hold duties, she was abused by her in-laws especially if she failed to make bhakris, her mother -in- law would yell like this:

Look at the bhakris this slut has prepared. She cannot even make a few bhakris properly. Oh, well, what can on expect of this daughter of a dunce? (94).

When a ritual was to be observed, the work of the women got doubled. They had to plaster their house with cow dung, and clean the utensils and the clothes. They lead a very pathetic life in their husband's home.Kemble dexterously depicts how a daughter-in- law is not safe even before a women of her own community but are always the target of taunts and put-downs and is frequently physically and psychologically tortured in her in- laws. Their mothers-in- law loved to give the same harsh treatment to them as they had received from their own in- laws which tell a lot about their sickconsciousness of having to inflict unnecessary pain to the immature younger girls and would even curse their mother if they fail to do a task. This is shown by the book in these lines:

what's your aai really? Tell me! Is she a good married woman at all? Or does she know only how to run after the pot-maker donkeys? Didn't she teach you anything? I pamper you... my own sasu was spitfire. A burning coal! Holding a burning coal in one's palm was easier than living with her! (95).

The condition of the Mahar women was wretched, worthless and most miserable. They had to do all the house hold duties, and go for selling wood to earn for their daily bread. They collected all the left- over from other 
Analyzing the Painful Recountal of Dalit Women in Baby Kamble's The Prisons We Broke

places to give them to their children. Most of the time women had to go on hunger unendingly.Dalit men never bothered toprovide nutritious and hygienic food to the new mothers.Women had to be forcibly content with only the gruel made from jowar. At the time of their delivery the midwives performed their jobs without any professional skill. Whenever they needed any sort of assistance they were left to the mercy of god. Kamblepaints the painful and pathetic condition of new mothers' as:

Many new mothers had to hungry. They would lie down, pining for a few morsels while hunger gnawed their insides. Mostly women suffered this fate. Labour pains, mishandling by the midwife wounds inflicted by onlookers' nails, ever gnawing hunger, infected wounds with pus oozing out, hot water baths, hot coals, profuse sweating - everything caused the new mothers' condition to worsen and she would end up getting a burning fever.(60 )

Kamble says that the Mahar women lives were limited to and bound by all domestic chores and they never had the provision of self-hygiene and self-care. Besides they were considered just as child procreating machines. "A mahar woman would continue to give birth till she reached menopause" (82). They were the worst victims of patriarchy, caste consciousness, gender proclivity and domestic violence. Kamble describe the pathetic situation of the Mahar women who are supposed to behave like slaves in presence of their upper caste Brahmans and are even instructed by their own men as to how to be at the beck and call of the upper caste hindus and take them as their masters.Asense of threat was instilled in them with regard to these upper caste sections of the community. Butfor their hardships, and laborious work for their masters, they earned curses and abuses as remuneration. Generations after generations, the Mahars served their masters very obediently. However the upper caste community threw abuses at the Mahars, if they did not fall at the feet of their masters, or if they did not give the way to their masters when the masters came across in their way.

They had to cover themselves fully if they saw any man from the higher casts coming down the road, when he came close, they had to say' the humble Mahar women fall at your feet master'. This was like a chant, which they had to repeat innumerable times, even to a small child if it belonged to a higher caste. (52)

The book narrates that a Dalit woman was always treated as a sexual object and was made available to upper caste men whenever they had a sexual urge. Dalit men were supposed to offer their wives to upper castes people to please them sexually in every possible manner.S. K. Limbale asserts boldly in his autobiographythat her mother was kept by several patils. He also tells that none of his siblings were born of the same father. However he firmly believesthat there was nothing wrong in the women itself but it was the inhuman customs and rituals fixed by upper caste sections that degraded Dalitwomen so low. He says

[...M]y mother was not an adultress but the victim of a social system. I grow restless whenever I read about a rape in the newspaper. A violation anywhere in the country, I feel, is a violation of my mother." (S.K.Limbale ix -Acknowledgement)

Kamble has exposed the hypocritical mentalmakeup of the upper caste sections of Indian society. Since the marginalization, victimization and enslavement of Dalits is based on this thinking that the Dalits are dirty and contaminated. They are treated as untouchables but such mentality is kept away whenever it comes to the benefit of those upper caste sections. In all indirect forms the upper caste Hindus are dependent on the Dalits. Kamble masterfully exposes these double standards of upper caste people like this:

www.arjonline.org

Page 3 
When Mahar women labour in the fields, the corn gets wet with their sweat. The same corn goes to make your pure, rich dishes. And you feast on them with such evident relish! Your palaces are built with the soil soaked with the sweat and blood of Mahars. But does it rot your skin? You drink their blood and sleep comfortably on the bed of their misery. Doesn't it pollute you then? (56)

Similarly on marriage occasion, the Brahmin priest would be invited to solemnize the marriage. The fear of getting polluted by Dalits makes the Brahmin priest sit at a distance. However he has no qualms in accepting Dakshina-money, and few kilosof pulses, rice, wheat and jiggery.

Dalit women shown in this text emerge as sandwiched between the Brahmanic and Dalit patriarchy as they are doubly oppressed.Dalit Community members were influenced by the joys of enslaving others enjoyed by the upper caste people and wanted to imitate their callous nature but they had no one to show their dominance. Thus they began to enslave the weaker sex in the form of their own daughters-in- law.Theywould treat the daughter-in- law like slavesbecause "she wasnot a human being for her in-laws but just another piece of wood. (99) Like High caste Hindus, Mahars wanted to become masters so they put their daughters-in- law as their slaves.It speaks volumes about the unfortunate lot of these daughters-in-law.Kamble provides the painful commentary on the plight of these women like this:

The other world had bound us with chains of slavery. But we too were human beings. And we too desired to dominate, to wield power. But who would let us do that? So we made our own arrangements to find slavesour very own daughters- in-laws! If nobody else , then we could at least enslave them. (87)

Though the text explores how the Brahmanic domination had turned the Mahars as worst as animals. Kamble secures a path for the emancipation of Dalit women through the ideology of Ambedkar. In the book the author talks about the influence of Dr. B.R. Ambedkar who was the light of their life. He asked the Mahars to educate their children, and inspired them to fight against the atrocities. He asked them not to give offerings to the gods who never cared about them and asked them not to eat the dead animals.Lambale has given due credit to the transformative thoughts of Ambedkar which helped the Dalits in elevating their social and economic postion. His ideas are put thus:

[F]rom now onwards you have to follow a different path. You must educate your children. Divorce your children from god. Teach them good things. Send them to schools. The result will be there for you to see. When your children begin to be educated, your conditions will start improving. Your family, your life will improve. Your children will bring you out of this hell. We are humans. We, too, have the right to live as human beings. (65).

The book, realistically and painfully, sketches the journey of the Mahar community from pre-Ambedkar era to its rapid transformation through education and mass conversion.

\section{CONCLUSION}

It is evident from this assessment that Kamble minutely and painfully portrays the tortures a Dalit woman had to undergo. She had to suffer domestic violence in the form of thrashing, physicaltorture, nose chopping, work overload and what not. She had no one to go to but had to suffer silently in many forms and on different stages. She had suffered because of her birth, because of her caste, because of her gender and because of her poverty. There are multiple layers of her sufferings enfolded for her. Life had been made a burden for her. Undoubtedly she had topay a heavy price for being born.

www.arjonline.org

Page 4 


\section{REFERENCES}

1. Kamble, Baby. 2009. 'Jina Amuche' translated by Maya Pandit as The Prisons We Broke. New Delhi: Orient Blackswan.

2. Rajinkar, Ashwin. “The Prisons We Broke: Saga of Dalit Women's Pathetic Condition” Retrieved from http:// ashwinranjanikar.blogspot.in/2013/11/dalit-women-autobiography-baby-kamble.html?m=1 Accessed 10.Dec2017

3. Rajput, Deepa. “Dalit among Dalits:Dalit women with special reference to Baby Kambale's The Prisons We Broke "GALAXY International. Interdisplinary Research Journal. VOL.2 Feb.2014 pp-139-143

4. Kumar ,Amit. “Caste and patriarchy dominate the lives of Dalit women in Baby Kamble's The Prisons We Broke" Research Scholar vol.3. issueIII. Aug2015. pp-174-180

5. Limbale, Sharankumar. Towards an Aesthetic of Dalit Literature: History, Controversies and Considerations. New Dellhi: Orient BlackSwan, 2014.

6. Shaily. "Trauma of Dalit Women as Thrice-Suppressed in Baby Kamble's The Prisons We Broke" Literary Herald VOL3. ISSUE. 2. 2017 pp-306-310

7. Kamble, Baby. The Prisons We Broke. Translated by Maya Pandit. $4^{\text {th }}$ ed., Orient Blackswan. 2014.

Citation: Mohd Nageen Rather, "Analyzing the Painful Recountal of Dalit Women in Baby Kamble's The Prisons We Broke" American Research Journal of English and Literature, vol 3, no. 1, 2017, pp. 1-5.

Copyright (c) 2017 Mohd Nageen Rather, This is an open access article distributed under the Creative Commons Attribution License, which permits unrestricted use, distribution, and reproduction in any medium, provided the original work is properly cited. 